\title{
DEVELOPING STUDENTS' RESPONSIBILITY THROUGH NUMBERED HEAD TOGETHER MODEL IN SOCIAL SCIENCE LEARNING AT ELEMENTARY SCHOOL
}

\author{
Harini Widyaningtyas, Retno Winarni, and Tri Murwaningsih \\ Sebelas Maret University \\ ningtyasharini@gmail.com,winarniuns@yahoo.com, and \\ murwaningsih_tri@yahoo.com \\ https://doi.org/10.24071/ijiet.v2i2.1035 \\ received 14 March 2018 ; revised 17 May 2018; accepted 10 July 2018
}

\begin{abstract}
This study is aimed at developing the application of responsibility through the implementation of Numbered Head Together model in the social science learning process. The type of this research was descriptive analysis using qualitative approach. The subjects of the study were the third-grade students and teachers of social science learning in Sukoharjo Sub-district. Data collection techniques inthis study were documentation studies, observation, and interviews. The findings of the research were analyzed using interactive analysis of Miles and Huberman model and presented through descriptive narrative text. The results of the researchshow that: 1) the learning result of the third-grade students in social science subject is not maximal yet, 2) the students are not aware of the social science learning objectives for their future, 3 ) the teachers remain applying the conventional model, 4) the teacher has not implemented the social science learning process involving the students' responsibility. The characteristics of Numbered Head Together learning model are suitable to be applied in learning social science because it makes the students serious in learning, develop thinking skills, and improve social relationships among students that can be used as a means to develop the students' responsibilities in the social studies learning process.
\end{abstract}

Keywords: numbered head together, responsibility, social science learning

\section{Introduction}

Education is the real effort in order to generate the learning process that can develop the students' potentials. To determine the maturity of children for school has a great significance for their further development (Velickovic, 2015). The potentials can be in the form of spiritual, intelligence, skill, andcharacter needed for themselves. The goal of every school is to be the best, to be failure-free and to make possible that every child learn it is own talents and capabilities (Delceva, 2014). The current education system in Indonesia bot only covers science but also the character building. The average age 
during primary school age is a critical phase to form the students' attitude or character (Prihandoko, 2017).

The treatment of the individual characteristics in the practice moves in two directions: first, creating a flexible education process by every teacher according to the individual potentials of the child/student; second, creating an educational context which is equal for every student in the same grade (Majovska, 2015). Character influences the students' mind-set that will affect the students to handle the situation. One of the students' influential characters is the learning responsibility. Responsibility is individuals' feeling in order to fulfill their tasks independently using their full commitment. Responsibility is the attitude to perform the obligations both in the family and school by giving the best. It can be synthesized that responsibility is an individual's attitude to perform obligations optimally using his or her own ability both in the scope of the family and school.

In relation to the learning process, the character of responsibility must be possessed by the student while performing the teachers' duties. Through the teachers' assignment, students can be responsible for completing the task carefully and on time (Rahayu, 2016). There are three indicators assessed from the learning responsibility, namely: submitting the task on time, doing the assignment as it is instructed, and doing the task independently. In addition, there are the others indicators of responsibility including: performing the tasks without prompting, showing initiatives to overcome problems, not cheating in doing the task. It can be concluded that the indicators of responsibility are as follows: involving in learning process seriously, doing individual tasks independently, doing group work together, completing tasks on time.

Based on the result of documentation study, the result of mid-term test in social science subject at SD Negeri Sukoharjo sub-district has not been optimal yet. The findings are also supported by the results of teacher interviews. The interviews revealed that the students have not comprehended the material of socialscience well IPS. It is due to the wide scope of social science material that are required to be mastered. It is also strengthened by the results of the observations that indicate that; 1) the students were not fully focused, 2) the students were less enthusiastic to follow-up the lessons, 3) the students frequently missed the classes,

4) the students did not submit the assignments on time, 5) the students disturbed other students while studying, 6) the students did not participate in group discussions, and 7) the students cheated while doing the individual task.

According to Sardiman (2010), social science subject that needs to be memorized is often considered to be boring and unattractive subject as well as the burden for the students. Meanwhile, social science is essential to be learnt due to its importance daily life. The design of the social science curriculum is aimed at helping the students introduce the world. Social science material is a basic concept of the introduction of the students' environment (Azizinezhad, 2013). Distinguishing the concept of the various parts of the environment is not easy for the students because they are required to understand each concept appropriately. Misconceptions will be worse if it is not fixed since the concepts taught at school become the foundation for the understanding of further material. 
Based on the results of documentation studies, interviews, and observation, the cause of social science learning outcomes that has not been optimal yet is students who are not responsible to involve in the learning process. The teachers need to address the problem by finding a solution. One of the solutions is through the implementation of innovative learning models. The selection of learning model can be adjusted to the students' characteristics. Therefore, it can affect the students' responsibility that possibly influence the results of social science learning. Eysink (2016) shows that innovative learning model in social science learning is aimed at easing the students' burden in mastering the material about the environment that has the wide scope. Learning model becomes the teacher's guidance in conducting the learning. Applying the right learning model will provide stimulus for students to be serious in learning.

Students need to be taught group skills to be motivated in learning and to take responsibility while following the learning process (Fatimah, 2012). One of the learning model that is considered suitable to be applied to develop the character of responsibility that is model of learning Numbered Head Together (NHT). NHT is a group learning activity by making sharing of reasons, then considering the right answers to solve the problem. The syntax of NHT is four, numbering, asking questions, thinking together, and answering questions (Firda, 2016). Syntax numbering is teacher divides the students into several groups and assign different numbers in one group. Syntax asking question is teacher asks questions to the students to be discussed with the group. Syntax thinking together that is when students discuss with the group. Syntax answering the question that is when the teacher randomly summons a number to perform in front of the class. The advantages of the NHT model are: students become ready, discuss seriously, and smarter students can help other students who have difficulty. Based on the excess of NHT, it is necessary to conduct a qualitative study on the application of the model when learning social science material of natural and artificial environment. Therefore, the purpose of this research is to develop the application of responsibility through the application of the Numbered Head Together (NHT) learning model in the social science learning process.

\section{Method}

The method used in this research is analytical descriptive. The subjects of the study were 111 third grade students and 4 teachers of social science subjects in elementary school, namely SD N Gayam 05, SD N Jetis 01, SD N Sukoharjo 01, SD N Joho 04 located in Sukoharjo sub-district, Sukoharjo regency 2017/2018. Data collection techniques used in this study are documentation studies, observation, and interviews. Documentation study was done through analysis of UTS result of social science subjects. Observation was completed during the learning process of social science took place with reference to the observation guidelines that had been prepared. Activities observed include aspects: learning models applied by teachers, and attitudes of students while following the learning process.

Interviews were conducted on four third grade teachers as subjects of social studies subjects. Interviews were used to obtain data, including: teachers' 
perceptions of the implementation of the social science learning process, student attitudes during the learning process of social science, teacher expectations on the development of social science material today. Technique of data analysis result of documentation study, interview, and observation using interactive analysis ofMiles and Huberman model. Analysis of interactive data on Miles and Huberman model was done through three steps: data reduction, data presentation, and conclusion. The result of data analysis of research findings then presented in qualitative form through narrative text to describe application of model of learningNumbered Head Together to student responsibility attitude.

\section{Findings and Discussion}

Research activities began with documentation study. Documentation study was done through analysis of final exam results of natural and artificial environment. The value of KKM (Criteria Completed Minimum) of four primary schools the same, which amounted to 70. UTS results showed from the fourth elementary school as many as 65 students or $58.56 \%$ who reached the value abovethe KKM, while 46 students or $41.44 \%$ has not achieved value above KKM. Learning outcomes show not yet optimal because there are still 46 students or 41,44\% who do not reach the value above KKM. Findings on learning outcomes that have not been optimal have relevance to the implementation of the learning process. Therefore the analysis of the learning process through observation activities.

Analysis of learning process of social science was conducted through observation when learning at SDN Gayam 05, SD N Jetis 01, SD N Sukoharjo 01, SD N Joho 04. The process of implementation of social science grade III teaching still applied KTSP curriculum. Focusing material on the natural and artificial environment at home and school. The results of observation showed: first, there were three elementary school which the learning process was still dominated by teacher's question and answer. There was one primary school that the teacher found to involve students in the learning process, such as group discussions, appoint students to answer questions, and made use of the school environment as an example of the material being taught. Second, the behavior of students who interfered with other students, students often permitted to restroom, students submitted tasks over time, and cheated the work of other students. Based on the observation, social science learning activities are limited to teachers transcribing materials about the natural and artificial environment to the students. Learning resources used were still limited, in the sense that teachers had not utilized the environment around the students optimally in order to support student learning responsibilities.

After observation of social science learning process, the researcher interviewed four grade 3 teachers of SDN Gayam 05, SD N Jetis 01, SD N Sukoharjo 01, and SD N Joho 04. Interview activities focused on the constraints experienced by teachers during social science learning process. Problems experienced by teachers with the source of learning, time, material, attitude of student responsibility in school. First, the constraints on social science source and teaching materials were limited to government guidance books, but there was one 
teacher who used the internet to add material references. Second, the constraint on time allocation social science that was not more than three hours lessons in a week, whereas social science material has a wide range, whereas for third grade students took a long time to absorb the material to be understood well. Third, natural and artificial environment materials had various concepts that must be mastered by students, but there were still students who had not been able to distinguish between mountain and hill, lake and swamp, or forest and garden. Fourth, the goal of social science learning is not yet realized by the students, whereas social science is a means of students to behave responsibly in the society, besides the social science material provides knowledge and experience about the life of the society which is always growing and changing.

Based on the results of documentation studies, observations, and interviews, appropriate solutions through the application of innovative learning models. The importance of applying the learning model to train students working group and train the responsibility for completing the task (Katrien, 2010). The Numbered Head Together (NHT) model aims to increase student activity in learning, to train leadership in making decisions, and to increase the character of learning responsibility (Agustin, 2013). This process allows students to interact with each other to exchange insights, be responsible for completing tasks, and generate confidence when expressing opinions.

Learning activities through the application of NHT models to natural and artificial environment materials can be preceded by material distribution. Material is made differently and the level of difficulty is gradual at each meeting. First, understanding and characteristics of the natural and artificial environment at home and school. Second, classify the types of natural and artificial environments at home and school. Third, the benefits of natural and artificial environments at home and school. Fourth, how to maintain or destroy the natural and artificial environment at home and school. Fifth, devise a new idea in the maintenance of natural and artificial environment at home and school.

The first syntax of the NHT model is numbering. Numbering is done after group formation and given to each member of the group. Group formation is done by teachers because it is considered to have understood the ability of each heterogeneous student. Students are not given freedom in the formation of groups because they tend to choose a friend who liked. The number works when the teacher calls the group representatives to present the results of the group discussion. Teachers do not designate certain students who are considered high or low. This is intended to involve all students in learning.

The second syntax of the NHT model is the questioning. The stage of asking questions to students is done on the core activities, i.e. after students receive and study the subject matter of the teacher. Questions were made in the form of group worksheets worked with groups. In this process the students do not know the number mentioned by the teacher to present the result of the discussion in front of the class. This process can make the students responsible for understanding the answers to the results of group discussions.

The third syntax of the NHT model is thinking together. Teachers provide group opportunities to work together to solve problems on group worksheets. This 
process allows each group to unite the head (this stage can be called head together) or discuss to think the answer that is considered most appropriate. Each member of the group has the same responsibility, because in addition to masteringthe answers, the student must also ensure all group members are able to answer questions from the teacher. Students are required to be unselfish with members of one group, students who have high ability must teach students who have low ability.

The syntheses of all four NHT models answer questions. After the students think together with the group, the students called the number forward to the class to present the results of the group discussion, while the unmarked student takes careful attention to the student who is presenting and responding. All students have the opportunity to present group answers. This process simultaneously trains students to express opinions, and communicates with other groups, in addition to this process indicating that all group members have equal opportunity to achieve success in learning. The teacher then rewards the best group, and guides the students to conclude the subject matter.

Based on the explanation of social science learning design through the application of NHT model, it is seen that the delivery of natural and artificial environment material is done gradually from the level material easy to difficult. The design of learning activities is oriented towards student-centered learning, interesting, and refers to the required material competence (Hartoyo, 2009). In addition to the material, the application of the NHT model demands a character that students must possess that is group and individual learning responsibilities. Group responsibilities are needed when students discuss with the group to complete tasks on time. Individual responsibility is required when students have to master the answers to the results of group discussions, and when students present the results of group discussions because the numbers are randomly selected by the teacher.

It should be noted that in applying the NHT model there may be some obstacles that teachers may experience. These constraints include large numbers of students and not even, there are students who are busy themselves outside of learning to interfere with other students, limited duration, less active student response, and low self-confidence of students. Therefore, these constraints need tobe anticipated by finding the right solution. First, a large number of obstacles cannot be anticipated by applying a random method of counting, for example the teacher wants to divide the class into 5 groups, each student counting one to five sequences according to the seat, students who mention the same number gathered into one group, this way is considered fair because it allows students to mingle with other students and do not choose a particular friend, besides the teacher can divide the group based on the level of student ability, for example students who have high ability are divided early and appointed as group leader, while other students divided by way of random method count. Second, the constraints of students who are busy with other activities outside of learning and tend to disturb other students can be anticipated by the way the teacher informs that the learning process is a group discussion but the results of the discussion are presentedindividually randomly appointed by the teacher. Third, limited time duration 
constraints can be anticipated by optimizing the time as effectively as possible, for example for each implementation of the teacher syntax to give the duration of time to be obeyed by the student, besides before the lesson starts the seating is arranged in groups. Fourth, passive student response constraints can be anticipatedby the way teachers require each group to make one question for the student whois presenting in front of the class. Fifth, low student confidence constraints can be anticipated by the way teachers build students 'self-confidence with applause, withthe clapping or singing spirit of the group can lead students to foster self-belief and guide students' courage for presentation in front of the class (Novitasari \& Abdullah, 2013).

Some of the constraints that may occur when applying the NHT model to social science learning can be anticipated with a solution tailored to the constraints. The goal is that in the future NHT model can be applied maximally, either for different class level or other subjects. The learning process through applying the NHT model gives students opportunities to build ideas and consider the most appropriate answers. Indirectly train students to share information, listen carefully, calculate answers appropriately, and cultivate student learning responsibilities, so students become more productive in learning. Therefore, through the application of the model of learning Numbered Head Together is expected to be a solution as a means for the development of the character of student responsibility.

\section{Conclusion}

Responsibility is the character possessed by individuals to perform obligations optimally with their own ability, both in the family and school. In relation to the learning process, the character of responsibility must be owned by the students, because it is required when carrying out the task given by the teacher. Indicators of learning responsibility include: taking the learning process seriously, doing individual tasks independently, doing group work together, completing tasks on time. Empirical facts of social science learning in the field have been analysed from various angles show that social science learning result not yet optimal. The cause of the students are less focused, not enthusiastic to follow the learning, often permit out when learning takes place, not timely collecting tasks, disturbing other students while studying, not participating during group discussions, and cheating while doing individual tasks. Some attitudes of students who are not good show that the attitude of student learning responsibility has not appeared on the students themselves. Efforts can be made to improve the learning process through the application of innovative learning models. The Numbered Head Together (NHT) learning model is a group learning activity by sharing reasons, then considering appropriate answers to solve problems. There are four NHT syntaxes that are numbering, asking questions, thinking together, and answering questions. Syntax numbering is the teacher divides the studentsinto several groups and gives students different numbers in one group. Syntax asks the question of the teacher asking questions to the students to be discussed with the group. Syntax thinking together is the stage when students discuss with the group. Syntax answer the question is a session when the teacher randomly call 
a certain number. The constraints that can occur when applying the NHT model need to be anticipated with solutions tailored to the constraints. The goal is that in the future NHT model can be applied maximally, either for different class level or other subjects. The learning process through applying the NHT model givesstudents opportunities to build ideas and consider the most appropriate answers. Indirectly train students to share information, listen carefully, calculate answers appropriately, and cultivate student learning responsibilities, so students become more productive in learning. Hence through the application of the model oflearning Numbered Head Together is expected to be a solution as a means for the development of character responsibility of students.

\section{References}

Agustin. (2013). The effect of using numbered head together technique on the eight grade students' reading comprehension achievement at SMPN 2 Tanggul Jember. Journal Pancaran, 2, 201-210.

Azizinezhad, M. (2013). Application of cooperative learning in EFL classes to enhance the students languange learning. Procedia-Social and Behavioral Sciences, 93,138-141.

Delceva, J. (2014). Classroom management. International Journal of Cognitive Research in Science Engineering and Education, 2(1), 51-56.

Eysink, T. (2016). Supporting Primary School Teachers in Differentiating in the Regular Classroom. Teaching and Teacher Education, 66, 107-116.

Fatimah, S. (2012). Pembelajaran fisika menggunakan model cooperative learning ditinjau dari prestasi belajar siswa. Jurnal Kependidikan, 42(1), 1-6.

Firdha. (2016). The effect of cooperative learning on mathematics learning outcomes viewed from students learning motivation. JRAMathEdu, 1, 49-55.

Hartoyo. (2009). Penerapan model pembelajaran kontekstual berbasis kompetensi untuk meningkatkan efektivitas pembelajaran. Jurnal Kependidikan, 39(1), 6778.

Mojovska. (2015). Possibilities of teaching for monitoring detectin and recording of individual characteristic of student in earliy moning. International Journal of Cognitive Research in Science Engineering and Education, 3(1), 93-98

Novitasari \& Abdullah. (2013). The implementation of numbered head together in teaching reading narrative text to the tenth graders. E-Journal Unesa, 1, 2-8.

Prihandoko, Y., St. Y. Slamet, \& Winarno. (2017). Pendekatan cognitive moral sebagai kerangka pengembangan bahan ajar ppkn di sekolah dasar. Jurnal Kependidikan, 1(2), 201-213.

Rahayu, R. (2016). Peningkatan karakter tanggung jawab siswa SD melalui penilaian produk pada pembelajaran mind maping. Jurnal Konseling Gusjigang, 2(1), 97-103.

Sardiman. (2010). Revitalisasi Peran pembelajaran ips dalam pembentukan karakter bangsa. Cakrawala Pendidikan, XXIX, 147-160.

Velickovic, S. (2015). The role of the preparatory preschool program for the school start of the children. International Journal of Cognitive Research in Science, Engineering and Education, 3(1), 105-110. 